\title{
PERLINDUNGAN HUKUM MASYARAKAT TERDAMPAK PENCEMARAN LINGKUNGAN OLEH INDUSTRI
}

\author{
Oleh : \\ ZAINAL ABIDIN \\ NIM. 18.6.9.0030 \\ PROGRAM PASCA SARJANA UNIVERSITAS SUNAN GIRI SURABAYA
}

\begin{abstract}
ABSTRAK
Hak atas lingkungan hidup yang baik dan sehat sebagaimana diatur dalam Pasal 28 (h) Undang-Undang Dasar Negara Republik Indonesia(UUD 1945) membawa implikasi hukum agar negara selalu menyediakan kualitas lingkungan yang sesuai dengan norma dasar UUD 1945 tersebut. Bahkan dalam Pasal 33 UUD 1945 telah diamanatkan bahwa "Bumi, air, dan kekayaan alam yang terkandung di dalamnya dikuasai oleh negara dan dipergunakan untuk sebesar-besar kemakmuran rakyat". Guna mewujudkan perlindungan terhadap lingkungan, maka pemerintah mengeluarkan berbagai kebijakan hukum yang terkait dengan masalah lingkungan hidup dan salah satu produk hukum yang sangat penting adalah Undang-undang Nomor 32 Tahun 2009 tentang Perlindungan dan Pengelolaan Lingkungan Hidup. UUPPLH telah memberikan dasar hukum yang sangat kuat mengenai perlindungan terhadap masyarakat untuk terhindar dari kualitas lingkungan yang tidak baik dan termasuk sengketa lingkungan hidup. Akan tetapi dalam pelaksanaanya penegakan lingkungan hidup masih terkendala oleh beberapa faktor maka dari itu perlu sosialisasi yang masif serta di buatkan aturan pelaksanaan sebagai penunjang UUPLH agar perlindungan terhadap masarakat terhadap pencemaran lingkungan dapat terwujut.
\end{abstract}

Kata Kunci: Perlindungan masyarakat, Lingkungan Hidup.

\section{ABSTRACT}

The right to a good and healthy environment as regulated in Article 28 (h) of the Constitution of the Republic of Indonesia (UUD 1945) has legal implications so that the state always provides environmental quality in accordance with the basic norms of the 1945 Constitution. Even in Article 33 of the 1945 Constitution it is mandated that "the earth, water and natural resources contained therein are controlled by the state and used for the greatest prosperity of the people". In order to realize the protection of the environment, the government issued various legal policies related to environmental issues and one of the most important legal products is Law Number 32 of 2009 concerning Environmental Protection and Management. The UUPPLH has provided a very strong legal basis regarding the protection of the community to avoid bad environmental quality and includes environmental disputes. However, the implementation of environmental enforcement is still constrained by several factors, therefore a massive socialization is needed and rules of implementation are made to support the UUPLH so that the protection of the community against environmental pollution can be threatened.

Keywords: Community Protection, Environment. 


\section{PENDAHULUAN}

\section{A. Latar Belakang Masalah}

Indonesia adalah salah satu regara yang berpotensi dengan berbagai surnber daya alam yang dimilikinya. Kandungan sumber daya alam yang dipunyai Indonesia sangat luar biasa. Sumber daya alam menurut Undang-Undang Nomor 32 Tahun 2009 tentang Perlindungan dan Pengelolaan Lingkungan Hidup, ${ }^{1}$ adalah "unsur lingkungan hidup yang terdiri atas sumber daya hayati dan non hayati yang secara keseluruhan membentuk kesatuan ekosistem". ${ }^{2}$

Hal tersebut tercermin dalam Pasal Undang-Undang Dasar Tahun $1945,{ }^{3}$ yang menyatakan : "setiap orang berhak hidup sejahtera lahir dan batin, bertempat tinggal, dan mendapatkan lingkungan hidup yang baik dan Sehat serta berhak memperoleh pelayanan kesehatan". ${ }^{4}$ Kondisi yang demikian itu dapat terwujud dengan berbagai cara. Misalnya, di bidang industri, pengusaha yang akan melakukan pembangunan atau kegiatan usaha, wajib memiliki Analisis Mengenai Dampak Lingkungan yang selanjutnya disebut dengan AMDAL. agar masyarakat yang tinggal di lingkungan sekitar tidak terkena polusi dari limbahyang dihasilkan, sesuai dengan Pasal 36 Ayat (1) UUPPLH, yaitu: "setiap usaha dan atau kegiatan wajib memiliki amdal atau UKL-UPL wajib memiliki izin lingkungan". ${ }^{5}$

Oleh karena itu, pengusaha yang akan melakukan pembangunan atau

\footnotetext{
${ }^{1}$ Selanjutnya Disebut UUPPLH

${ }^{2}$ Undang-Undang Nomor 32 Tahun 2009

Tentang Perlindungan Dan Pengelolaan Lingkungan Hidup Pasal 1 Angka 8.

${ }^{3}$ Selanjutnya Disebut Uud 1945

${ }^{4}$ Undang-Undang Dasar Negara Republik Indonesia Tahun 1945 Pasal 28 H Ayat (1)

${ }^{5}$ UUPPLH, Op.Cit, Pasal 36 Ayat (1)
}

kegiatan usaha, tidak cukup hanya memperhatikan pilihan teknologi dan mengejar keuntungan semata, tetapi harus dikaji dan dipertimbangkan juga aspekaspek lingkunganya. Agar lingkungan hidup tetap tejaga kelestariannya UndangUndang Nomor 32 Tahun 2009 tentang Perlindungan dan PengelolaanLingkungan Hidup, mengatur secara lebih menyeluruh tentang perlindungan dan pengelolaan lingkungan hidup. Dan akan mendapatkan sanksi terhadap siapa saja yang melakukan kejahatan lingkungan.

Perkembangan pembangunan, teknologi, industrialisasi yang dibarengi dengan pertumbuhan penduduk yang semakin pesat membawa dampak pada lingkungan. Dampak suatu kegiatan terhadap lingkungan antara lain adalah terjadinya bencana banjir, kekeringan, erosi tanah, pencemaran lingkungan, berupa antara lain pencemaran air, dan pencemaran udara, matinya beberapa jenis tumbuhan dan hewan bahkan kematian terhadap manusia. Bila kita telaah penyebab utama terjadinya pencemaran dan atau pengrusakan itu disebabkan terutama karena ulah manusia yang tidak atau kurang kepeduliannya terhadap lingkungan Pencemaran lingkungan hidup tidak hanya berdampak buruk bagi kehidupan masyarakat yang ada sekarang namun juga akan mengancam kelangsungan hidupnya kelak. Oleh karena itu baik masyarakat, maupun pemerintah berhak dan wajib untuk melindungi lingkungan hidup.

Masyarakat diharapkan secara aktif dapat berperan dalam perlindungan dan pengelolaan lingkungan hidup. Pemerintah hendaknya berupaya terus memberikan perlindungan bagi lingkungan hidup negaranya melalui berbagai program 
yang sesuai dengan koridor peraturan perundang-undangan yang berlaku. Guna mewujudkan perlindungan terhadap lingkungan, maka pemerintah mengeluarkan berbagai kebijakan hukum yang terkait dengan masalah lingkungan hidup dan salah satu produk hukum yang sangat penting adalah Undangundang Nomor 32 Tahun 2009 tentang Perlindungan dan Pengelolaan Lingkungan Hidup. UUPPLH telah memberikan dasar hukum yang sangat kuat mengenai perlindungan terhadap masyarakat untuk terhindar dari kualitas lingkungan yang tidak baik dan termasuk sengketa lingkungan hidup.

Upayauntuk memberi perlindungan dan pengelolaan lingkungan hidup menjadi conditio sine qua non yang artinya setiap akibat dapat ditentukan sebab -sebabnya dan masing-masing sebab memiliki pengaruh terhadap terjadinya suatu akibat untuk dilakukan secara konsisten dalam pembangunan nasional yang berkelanjutan. Hukum lingkungan menjadi sarana yang dapat diandalkan untuk melindungi dan mengelola lingkungan hidup karena hukum lingkungan selain mempunyai fungsi pencegahan (prevention function) juga sekaligus memiliki fungsi menindak (law enforcement) setiap terjadi perusakan dan/atau perusakan lingkungan yang ditimbulkan oleh subyek hukum akibat usaha dan/atau kegiatan yang dilakukannya.

Melihat dari kasus pencemaran lingkungan, masyarakat adalah pihak yang dirugikan atas tindakan pencemaran lingkungan. Masyarakat tidak mampu mengajukan sendiri kompensasi, baik kompensasi berupa ganti rugi maupun tindakan perbaikan/ pemulihan lingkungan, karena alasan ketidaktahuan peraturan perundangan yang akan dijadikan pijakan penuntutan maupun faktor biaya yang bagi mereka masih menjadi keragu-raguan karena dibayangi akan resiko kalah bila menuntut ke Pengadilan. Kompleknya permasalahan lingkungan sebagai bidang relatif baru sangat potensial menimbulkan perbedaan pandangan, kepentingan atau persepsi diantara para "stakeholders". Manakala pandangan tentang lingkungan hidup masih beranjak dari kepentingan masing-masing, maka konflik akan selalu muncul.

Hukum lingkungan juga telah memberikan dasar hukum agar masyarakat mendapatkan perlindungan hukum dalam setiap tahapan dalam penyelesaian sengketa lingkungan hidup.

Berdasarkan uraian diatas "penulis melakukan penelitian berjudul " Perlindungan Hukum Masyarakat Terdampak Pencemaran Lingkurngan Oleh Industri"

\section{B. Rumusan Masalah}

Berdasarkan latar belakang tersebut dapat dikemukakan beberapa permasalahan mengenai perlindungan masyarakat dalam sengketa lingkungan hidup antara lain :

1. Bagaimana Ketentuan tentang Hukum lingkungan berdasarkan UndangUndang Nomor 32 Tahun 2009 tentang Perlindungan dan Pengelolaan Lingkungan Hidup ?

2. Bagaimana perlindungan hukum masyarakat terdampak pencemaran lingkungan, dan penegakan hukum serta kendala yang dihadapi? 


\section{Tujuan Penelitian}

Penulisan Tesis diajukan untuk memenuhi sala satu persyaratan kurikulum akademis dan untuk memperoleh gelar Magister Hukum pada Fakultas Hukum Universitas Sunan Giri Surabaya. Di samping itu untuk mengembangkan pemikiran masalah hukum yang dihadapi masyarakat. Mengetahui lebih jauh bagaimana peran serta masyarakat mengaktualisasikan perlindungan dan pengelolaan lingkungan hidup sebagai masyarakat kita dapat menikmati lingkungan sekitar kita.

\section{Manfaat Penelitian}

\section{Manfaat Teoritik}

Penelitian ini diharapkan untuk memberikan referensi baru mengenai hukum di Indonesia, terutama yang menekankan pada konsep hukum mengenai Perlindungan Hukum terhadap masyarakat terdampak pencemaran lingkungan berdasarkan Undang-Undang Nomor 32 Tahun 2009 Tentang Perlindungan Dan Pengelolaan Lingkungan Hidup.

2. Manfaat Praktis.

Dengan menitik beratkan pada penelitian mengenai Perlindungan hukum,upaya dan mekanisme Penyelesaian sengketa Lingkungan Hidup, penulis ingin memberikan gambaran tentang proses Tersebut menurut ketentuan perturan perundang-undangan dan turunanya mengenai lingkungan hidup, dengan harapan agar dapat membantu masyarakat untuk mendapatkan kepastian hukum mengenai perlindungan hukum masyarakat terdampak pencemaran lingkungan oleh industri.

\section{KAJIAN TEORI}

\section{A. Pengertian Hukum Lingkungan} Hidup.

Menurut St. Munadjat Danu saputro, hukum lingkungan itu dapat dibedakan atas hukum lingkungan klasik yang berorientasi pada penggunaan lingkungan (use-oriented law) dan hukum lingkungan modem yang berorientasi pada lingkungan itu sendiri (environment oriented Iaw).

Dalam pandangan A.V. van den Berg, pengelolaan lingkungan hidupitu berhadapan dengan hukum sebagai sarana kepentingan ligkungan yang dibedakan sebagai berikut: ${ }^{6}$

1) Hukum bencana (rampenrecht);

2) Hukum kesehatan lingkungan (milieuhygienerecht);

3) Hukum tentang sumber daya alam atau konservasi (recht betreffendenatuurlijke rijkdommen);

4) Hukum tata ruang (rechtbetreffende de verdeling van het ruimtegebruik);

5) Dan hukum perlindungan lingkungan (milieubeschermingsrecht).

Sementara menurut Koesnadi Hardjasoemantri, apabila berdasarkanaspek, maka hukum lingkungan itu meliputi: ${ }^{7}$

1) Hukum tata lingkungan;

2) Hukum perlindungan lingkungan;

3) Hukum kesehatan lingkungan;

4) Hukum pencemaran lingkungan;

5) Hukum lingkungan internasional; dan

6) Hukum perselisihan lingkungan.

${ }^{6}$ Ibid, Hal. 3.

${ }^{7}$ Koesndi Hardja Soemantri, Hukum Tata Lingkungan. Yogyakarta, Gajah Mada Press, Hal. 15. 
Keberadaan hukum tata Iingkungan terletak pada tata penyelenggaraan tugas (hak dan kewajiban) kekuasaan negara berikut alat kelengkapannya dalam mengatur pengelolaan lingkungan hidup. Untuk hukum perlindungan lingkungan berada pada pengaturan di bidang pengelolaan lingkungan hidup yang berkaitan dengan lingkungan biotik sampai batas tertentu juga dengan lingkungan antrophogen yang wujud strukturalnya meliputi perlindungan hayati, non hayati, buatan, termasuk cagar budaya.

Sementara terhadap hukum kesehatan lingkungan berada pada kaitannya dengan kebijaksanaan di bidang kesehatan lingkungan yang wujud strukturalnya meliputi pemeliharaan kondisi air, tanah, dan udara. Terhadap hukum pencemaran lingkungan hanya ditekankan pada pengaturan terhadap pencegahan dan penanggulangan pencemaran yang wujud strukturalnya meliputi pencemaran air, udara, dan tanah. Kemudian, untuk hukum lingkungan internasional terlingkup pada pengaturan hubungan hukum mengenai sengketa lingkungan yang sifatnya melintasi batasbatas negara. Adapun untuk hukum perselisihan lingkungan melingkupi pengaturan mengenai prosedur pelaksanaan hak dan kewajiban karena adanya perkara lingkungan. ${ }^{8}$

\section{Masalah-masalah Lingkungan hidup.}

Pengertian perusakan lingkungan sebagaimana dirumuskan dalam Pasal 1 butir 14. yaitu:tindakan yang menimbulkan perubahan hngsung atau tidak langsung herhadap sifat Esik dan/atau hayati yang mgakibatkan lingkungan hidup tidak

${ }^{8}$ Ibid, Hal. 36. berfungsi lagi dalam menunjang pembangunan berkelanjutan.

Dampak negatif dari menurunnya kualitas lingkungan hidup baik karena terjadinya pencemaran atau terkurasnya sumber daya alam adalah timbulnya ancaman atau dampak negatif terhadap kesehatan, menurunnya nilai estetika, kerugian ekonomi (economic cost), dan terganggunya sistem alami (natural system).

a. Kesehatan

b. Estetika.

c. Kerugian Ekonomi.

d. Terganggunya Ekosistem alami.

\section{Faktor-faktor terjadinya Masalah Lingkungan.}

a.Teknologi.

b. Pertumbuhan Penduduk.

c. Motif Ekonomi.

d. Tata Nilai.

\section{B. Pengertian Industri.}

Pengertian Industri menurut Undang-Undang Nomor 3 tahun 2014 tentang Perindustrian adalah sebagai berikut: "Perindustrian adalah tatanan dan segala kegiatan yang bertalian dengan kegiatan industri."

Adapun berdasarkan peraturan perundang-undangan tertentu, suatu badan usaha diwajibkan berbentuk badan hukum dalam hal menjalakan kegiatan usaha seperti Bank, Rumah Sakit, penyelenggara satuan pendidikan formal. Selain itu, apabila terdapat penyertaan modal asing dalam badan usaha tersebut, maka badan usaha tersebut wajib untuk berbentuk badan hukum yaitu Perseroan Terbatas. Sehingga apabila dalam perkembangannya Perusahaan Dagang/Usaha Dagang akan melakukan kegiatan usaha sebagaimana 
disebutkan sebelumnya dan/atau terdapat penyertaan modal asing dalam badan usahanya, maka Perusahaan Dagang/Usaha Dagang tersebut wajib untuk berbentuk badan hukum. berikut kami uraikan karakteristik untuk beberapa badan usaha baik yang merupakan badan hukum atau bukan badan hukum.

\section{Badan Usaha Berbentuk Badan Hukum}

Karakteristik suatu badan hukum yaitu terdapat pemisahan kekayaan pemilik dengan kekayaan badan usaha, sehingga pemilik hanya bertanggung jawab sebatas harta yang dimilikinya. Badan usaha yang berbentuk badan hukum terdiri dari:

a. Perseroan Terbatas

Berdasarkan Pasal 1 ayat

Peraturan Pemerintah Nomor 29 Tahun 2016 tentang Perubahan Modal Dasar Perseroan Terbatas ("PP 29/2016") besaran modal dasar PT ditentukan berdasarkan kesepakatan para pendiri Perseroan Terbatas. Modal dasar Perseroan Terbatas tersebut harus ditempatkan dan disetor penuh paling sedikit $25 \%$ yang dibuktikan dengan bukti penyetoran yang sah; ${ }^{9}$

b. Yayasan

Pasal 1 angka 1 Undang-Undang Nomor 16 Tahun 2001 tentang Yayasan ("UU Yayasan) sebagaimana telah diubah dengan Undang-Undang Nomor 28 Tahun 2004 tentang Perubahan Atas UndangUndang Nomor 16 Tahun 2001 Tentang Yayasan ("UU 28/2004") menjelaskan bahwa yayasan merupakan badan hukum yang terdiri atas kekayaan yang dipisahkan dan diperuntukkan untuk mencapai tujuan tertentu di bidang sosial, keagamaan dan

9 Peraturan Pemerintah Nomor 29 Tahun 2016 Tentang Perubahan Modal Dasar Perseroan Terbatas, Pasal 2 Ayat (1) kemanusiaan yang tidak mempunyai anggota;

c. Koperasi

Berdasarkan Pasal 1 angka 1 Undang-Undang Nomor 25 Tahun 1992 tentang Perkoperasian ("UU Koperasi") koperasi adalah badan usaha yang beranggotakan orang-seorang atau badan hukum koperasi dengan melandaskan kegiatannya berdasarkan prinsip Koperasi sekaligus sebagai gerakan ekonomi rakyat berdasar atas asas kekeluargaan. ${ }^{10}$

\section{Badan Usaha Bukan Berbentuk Badan Hukum}

Lain halnya dengan badan usaha yang bukan berbentuk badan hukum, pada bentuk badan usaha ini, tidak terdapat pemisahan antara kekayaan badan usaha dengan kekayaan pemiliknya. Badan usaha bukan berbentuk badan hukum terdiri dari:

a. Persekutuan Perdata

Dijelaskan dalam Pasal 1618 Kitab Undang-Undang Hukum Perdata ("KUHPerdata") bahwa persekutuan perdata (maatschap) adalah perjanjian di mana dua orang atau lebih mengikatkan diri untuk memasukkan sesuatu ke dalam persekutuan dengan maksud untuk membagi keuntungan yang terjadi karenanya.

b. Firma

Pasal 16 Kitab Undang-Undang Hukum Dagang (“KUHD”) menjelaskan bahwa firma merupakan suatu perseroan yang didirikan untuk melakukan suatu usaha di bawah satu nama bersama. Para anggota memiliki tanggung jawab renteng terhadap firma. ${ }^{11}$

\footnotetext{
${ }^{10}$ Undang-Undang Nomor 25 Tahun 1992 Tentang Perkoperasian, Pasal 1 Angka 1 Pasal 18
} 
c. Persekutuan Komanditer (“CV”)

Terdiri dari pesero aktif dan pesero pasif/ komanditer. ${ }^{12}$ Pesero aktif bertanggung jawab sampai dengan harta pribadi, sedangkan pesero pasif hanya bertanggung jawab sebesar modal yang telah disetorkan ke dalam $\mathrm{CV}$.

\section{Pencemaran dan Perusakan Lingkungan}

Arti dari pencemaran dan perusakan lingkungan hidup sebagai berikut:

1. Pencemaran lingkungan adalah masuk atau dimasukkannya makhluk hidup, zat, energi, atau komponen lain ke dalam lingkungan hidup oleh kegiatan manusia sehingga melampaui baku mutu lingkungan hidup yang telah ditetapkan.

2. Perusakan lingkungan adalah tindakan orang yang menimbulkan perubahan langsung atau tidak langsung terhadap sifat fisik, kimia,dan/atau hayati lingkungan hidup sehingga melampaui kriteria bakukerusakan lingkungan hidup.

\section{Bentuk - Bentuk Pencemaran}

\section{Lingkungan.}

lstilah pencemaran (pollution) digunakan untuk melukiskan bagaimana keadaan alam yang lebih berat dari sekadar pengotoran belaka, misalnya apabila pakaian kita kotor dapat segera dicuci, Pasal 19 kemudian dapat kita pakai kembali. Lain halnya dengan pakaian yang tercemar oleh tinta atau lebih lagi oleh jamur, maka pakaian tersebut akan merosot dalam kegunaan dannilainya, bahkan mungkin mengalami kerusakan.

Dalam perkembangannya, istilah "pencemaran lingkungan" mengalami kekhususan sebagaimana berikut: pencemaran air, pencemaran daratan, pencemaran laut, pencemaran udara, pencemaran angkasa, pencemaran pandangan, pencemaran rasa, pencemaran kebudayaan, bahkan wakil negara Kenya, pernah juga menampilkan pengertian tentang pencemaran hati nurani pada saat ia berbicara dalam Konferensi PBB tentang lingkungan hidup manusia di Stockholm pada tahun 1972. Apabula menunjuk pada gejala apartheid politic di Afrika Selatan. ${ }^{13}$

\section{Perkembangan}

Peraturan

\section{Perundang-Undangan.}

\section{Peraturan Perundang-undangan Lingkungan Klasik}

Praturan perundang-undangan yang dibuat sebelul tanggal 11 Maret 1982 dipandang sebagai rezim hukum lingkungan nasional klasik, Sedangkan peraturan perundan-undangan yang dibuat sejak maret 1982 dipandang sebagal rezim hukum lingkungan national moderen. Perbedaan pokok antara rezim hukum lingkungan klasik dan rezim hukum lingkungan moderen adalah terletak pada ruang lingkup dan pandekatannya. Rezim hukum Iingkungan klasik berisikan ketentuan-ketentuan yang melindungi kepentingan sektoral, sedangkan ketentuan- ketentuan hukum lingkungan

${ }^{13}$ St. Munajat danu saputro, Hukum Lingkungan Melandasi Hukum Pencemaran, Buku V, Sektor, Binacipta,Bandung,1986,Hal.35. 
moderen berdasarkan pendekatan lintas sektoral atau komperhensif intergal.

\section{Sejarah singkat pembentukan} Undang-Undang Nomor 4 Tahun 1982 Tentang Ketentuan Pokok Pengelolan Lingkungan Hidup

$1982 \begin{array}{ccc}\text { Undang-Undang Nomor } 4 & \text { Tahun } \\ \text { Tentang Ketentuan } & \text { Pokok }\end{array}$
Pengelolan Lingkungan Hidup, ${ }^{14}$ memang tidak lagi berlaku 23 Tahun 1977, juga dinyatakan tidak berlaku oleh UU Nomor 32 Tahun 2009 tentang Perlindungan dan Pengelolaan Lingkungan Hidup. ${ }^{15}$ perlu dibahas UULH 1982 secara singkat karena undang-undang itu mempakan undangundang tentang pengelolaan lingkungan hidup yang pertama diundangkan di Indonesia setelah munculnya kasadaran global dan nasional tentang arti pentingnya pengelolaan lingkungan. Selain itu, UULH 1982 dapat dipandang sebagai undangundang tentang pegeolalan lingkungan hidup pada masa moderen karna memuat konsep-konsep dan instrumen-instrumen pengelolaan lingkungan hidup, misalkan baku mutu lingkungan hidup dan analisis mengenai dampak lingkungan yang tidak ditemukan dalam peraturan perundangundangan klasik.

\section{Undang-Undang Nomor 4 Tahun} 1982 Ke Undang-Undang Nomor 32 Tahun 2009 Tentang Perlindungan dan Pengelolaan Lingkungan Hidup.

UULH 1997 tetap memuat konsepkonsep yang semula dituangkan dalam UULH 1982, misalnya kewenangan negara, hak dan kewajiban masyatakat dalam pengelolaan lingkungan hidup. 1982.

14 Selanjutnya Disebut Dengan UULH

${ }^{15}$ Lembar Negara Nomor 140 Tahun 2009 perizinan, Amdal, penyelesaian sengketa dan sanksi pidana. Selain itu, UULH 1997 memuat konsep-konsep atau hal- hal yang sebelunmya tidak diatur dalam UULH 1982. Misalnya, di bidang hak masyarakat, UULH 1997 mengakui hak masyarakat untuk mendapatkan informasi. Di bidang instrumen pengelolaan lingkungan, UULH 1997 mengatur penerapan audit lingkungan. Di bidang penyelesaian sengketa, UULH 1997 mengatur penyelesaian sengketa melalui pengadilan dan penyelesaian sengketa di luar pengadilan atas dasar kebebasan memilih para pihak .Dibidang sanksi pidana, UULH 1997 memberlakukan delik formil di samping materiil dan delik korporasi.

Perkembangan Terbaru adalah Pemerintah mengundangkan UndangUndang Nomor 32 Tahun 2009 tentang Perlindungan dan Pengelolaan Lingkungan Hidup yang menggantikan UULH 1997. UU ini secara normatif dan politik merupakan produk dari hak inisiatif DPR RI. Tetapi, secara empiris peran eksekutif, khususnya Kementerian Lingkungan Hidup sangat penting dalam mempersiapkan Rancangan UndangUndangPerlindungan Pengelolaan Lingkungan Hidup. ${ }^{16}$

E. Konsep Pengelolaan Lingkungan Hidup dan Beberapa Pengertian Konsep Dalam UndangUndang Nomor 32 Tahun 2009 Tentang Perlindungan dan Pengelolaan Lingkungan Hidup

Beberapa konsep atau istilah baru yang dirumuskan dalam UUPLH dan tidak ditemukan dalam UULH 1997 maupun UULH 1982 adalah kajian lingkungan

${ }^{16}$ Selanjutnya dIsebut dengan RUUPPLH. 
hidup strategis, disingkat KLHS, kerusakan lingkungan hidup, perubahan iklim, bahan berbahaya dan beracun, limbah bahan berbahaya dan beracun; pengelolaan limbah B3, dumping, audit lingkungan hidup, ekoregion, kearifan lokal, masyarakat hukum adat, instrumen ekonomi, ancaman serius, izin lingkungan. ${ }^{17}$

Kajian lingkungan hidup strategis (KLHS) adalah "rangkaian analisis sistematis, menyeluruh dan partisipatif untuk memasukan bahwa prinsip pembangunan berkelanjutan telah menjadi dasar dan terintegrasi dalam pembengunan suatu wilayah dan/atau kebijakan, rencana dan/atau prng dirumuskan dalam pasal 1 butir 10 UUPLH merupakan instrumen perencanaan dan program.

Pengertian perubahan iklim dirumuskan dalam Pasal 1 butir 19 yaitu berubahnya iklim yang diakibatkan langsung atau tidak langsung oleh aktivitas manusia sehingga menyebabkan pembahan komposisi atmosfer secara global dan selain itu juga berupa perubahan variabilitas iklim alamiah yang teramati pada kurun waktu yang dapat dibandingkan.

Pengertian lingkungan hidup sebagaimana dirumuskan Pasal 1 butir 1 UUPPLH adalah: "kesatuan ruang dengan semua benda, daya, keadaan, danmakhluk hidup, termasuk manusia dan perilakunya yang memengaruhi alam itu sendiri, kelangsungan perikehidupan dan kesejahberaan manusia serta makhluk hidup lain.

Pengertian pembangunan berkelanjutan, sebagaimana dirumuskan dalam Pasal 1

17 Takdir Rahmadi, Hukum Lingkungan Di Indonesia, Rajawali Pres, Jakarta, 2014, Hal.57. butir 3 UUPPLH, adalah "upaya sadar dan terencana, yang memadukan lingkungan hidup, sosial ekonomi ke dalam strategi pembangunan untuk menjamin keutuhan lingkungan hidup serta keselamatan, kemampuan, kesejahteraan dan mutu hidup generasi masa kini dan masa depan.

Pengertian ekosistem sebagamana dirumuskan dalam UUPPLH adalah “ tatanan unsur lingkungan hidup yang merupakan kesatuan untuk menyeluruh dan saling mempengaruhi dalam membentuk keseimbangan, stabilitas dan produktivita lingkungan hidup."18

Pengertian sumber daya alam sebagaimana dirumuskan Pasal 1 ayat 9 UUPPLH adalah: "unsur lingkungan hidup yang terdiri atas sumber daya alam, baik hayati maupun non-hayati yang secara kaeluruhan membentuk ksaman ekosistem.

Pengertian analisis mengenai dampak lingkungan, disingkat Amdal, sebagaimana dirumuskan dalam Pasal 1 butir $11 \quad 10$ adalah 'kajian mengenai dampak penting suatu usaha dan/atau kegiatan yang direncanakan pada lingkungan hidup yang diperlukan bagi proses pengambilan keputusan tentang penyelenggaran usaha dan/atau kegiatan.

Pengertian baku mutu lingkungan sebagaimana dirumuskan dalam Pasal 1 butir 13 adalah: "ukuran batas atau kadar makhluk hidup, zat, energi, atau komponen yang ada atau harus ada dan/ atau unsur pencemar yang ditenggang keberadaannya dalam suatu sumber daya tertentu sebagai unsur dalam lingkungan hidup." Rumusan ini sama dengan rumusan dalam UULH

\footnotetext{
${ }^{18}$ Undang-Undang Nomor 32 Tahun 2009 Tentang Perlindungan Dan Pengelolaan Lingkungan Hidup Pasal 1 butir 5.
} 
1997 dan juga dengan rumusan UULH 1982. ${ }^{19}$

Pengertian pencemaran lingkungan sebagaimana dirumuskan alam Pasal 1 butir 14 UUPPLH adalah "masuknya atau dimasukanya makluk hidup, zat energi, atau komponen lain kedalam lingkungan hidup oleh kegiatan manusia sehingga melampaui baku mutu lingkungan hidup yang ditetapkan.

Pengertian perusakan Iingkungan sebagaimana dirumuskan dalam Pasal 1 butir 16 UUPPLH adalah "tindakan orang yang menimbulkan perubahan langsung atau tidak langsung terhadap sifat-sifat fisik dan/ atau hayati lingkungan sehingga melampaui kriteria baku kerusakan lingkungan hidup.

Pengertian konservasi sumber daya alam sebagaimana dirumuskan dalam Pasal 1 butir 18 adalah "pengelolaan sumber daya alam yang menjamin pemanfaatan secara bijaksana dan bagi sumber daya terbarui menjamin kesinambungan persediaannya dengan tetap memelihara dan meningkatkan kualitas nilai dan keanekaragamannya.

Pengertian dampak lingkungan sebagaimana dimmuskan dalam Pasal 1 butir 26 adalah "pengaruh perubahan pada lingkungan hidup yang diakibatkan oleh suatu usaha dan/ atau kegiatan.

\section{METODOLOGI PENELITIAN}

Metode yang digunakan dalam penelitian ini adalah yuridis nolmatif, yaitu melakukan penelitian dengan cara menelaah berdasarkan kaedah-kaedah dan norma hukum. Dalam penelitian ini, hukum dikonsepkan sebagai apa yang tertulis dalam peraturan perundang-

${ }^{19}$ Ibid. Hal. 60. undangan (law in books) atau hukum di konsepkan sebagai kaidah atau norma yang merupakan patokan berperilaku manusia yang di anggap pantas.

\section{HASIL PENELITIAN DAN PEMBAHASAN}

\section{A. Pengaturan Penyelesaian Sengketa Lingkungan Hidup}

UUPPLH hanya menekankan sengketa lingkungan dalam aspek penegaka hukum lingkungan keperdataan. Hukum Lingkungan mengedepankan penyelesaian sengketa lingkungan melalui jalur hukum administrasi ("administrative litigation") ,karena langsung menggugat penghentian pencemaran dan/atau perusakan lingkungan. Di Belanda, penyelesaian sengketa lingkungan memprioritaskan gugatan ke lembaga Peradilan Administrasi ("appeals to the administrative courts").

Peradilan Administrasi sebagai sarana penyelesaian sengketa lingkungan terhadap kasus pencemaran udara di Indonesia berkaitan dengan penerbitan “izinlingkungan”, sebagaimana dituangkan dalam rumusan "sengketa tata usaha negara", menurut Pasal 1 angka 4 Undang-Undang Peradilan Tata Usaha Negara. Sengketa Tata Usaha Negara, mengandung unsur: subyek sengketa adalah orang atau badan hukum perdata dan Badan atau Pejabat TUN dengan obyek sengketa KTUN. ${ }^{20}$

\section{Gugatan Melalui Badan Peradilan Administrasi}

UU PERATUN merupakan dasar hukum pengajuan gugatan administrasi

\footnotetext{
${ }^{20}$ KTUN Singkatan dari Keputusan Tata
} Usaha Negara. 
atas KTUN perizinan lingkungan yang dewasa ini diatur dalam Peraturan pemerintah Nomor 27 Tahun 2012 tentang Perizinan Lingkungan. Dalam prakteknya terdapat beragam jenis izin yang dikategorisasikan sebagai jenis izin dengan aspeklingkungan, misalnya: Izin HO, Izin Usaha Industri, IPLM, Izin Lokasi, Izin Usaha Angkutan, Izin Trayek, Izin Operasi Angkutan maupun Surat Izin Mengemudi, dan lain-lain jenis izin yang berdampak lingkungan, yang dianggap "onrechtmatig" dan dapat menimbulkan terjadinya pencemaran udara. Bertolak dari Pasal 53 ayat (1) dan Pasal 1 angka 4 UU PERATUN: izin lingkungan dapat digugat di lembaga Peradilan Administrasi yang berisi tuntutan (petitum) agar KTUN (izin lingkungan) yang disengketakan dinyatakan batal atau tidak sah dengan tujuan untuk menghentikan pencemaran udara atas dasar prinsip "abatement at the source,. ${ }^{21}$

\section{Mekanisme Gugatan Lingkungan}

Undang-Undang Perlindungan dan Pengelolaan Lingkungan Hidup mengatur

1) Penyelesaian sengketa lingkungan hidup dapat ditempuh melalui pengadilan atau di luar pengadilan.

2) Pilihan penyelesaian sengketa lingkungan hidup dilakukan secara suka rela oleh para pihak yang bersengketa.

3) Gugatan melalui pengadilan hanya dapat ditempuh apabila upaya penyelesaian sengketadi

\footnotetext{
${ }^{21}$ Suparto Wijoyo, kajian Hukum Tentang Perlindungan Kepada Masyarakat Dalam Sengketa Lingkungan Hidup, Hal.28
}

luar pengadilan yang dipilih dinyatakan tidak berhasil oleh salah satu atau para pihak yang bersengketa. $^{22}$

\section{Dasar Hukum Gugatan Lingkungan}

UU PPLH mengakui " hak setiap orang atas lingkungan hidup yang baik dan sehat sebagai bagian dari hak asasi manusia. ${ }^{23}$ "disamping"berkewajiban memelihara kelestarian fungsi lingkungan hidup serta mengendalikan pencemaran dan/atau kerusakan lingkungan hidup". ${ }^{24}$

\section{Penyelesaian Kasus Lingkungan Hidup melalui Jalur Pengadilan dan di Luar Pengadilan.}

a. Penyelesaian Kasus Lingkungan Hidup di luar Jalur Pengadilan

Undang-undang Nomor 32 tahun 2009 yang menyatakan bahwa penyelesaian sengketa lingkungan hidup dapat ditempuh melalui pengadilan atau di luar pengadilan. ${ }^{25}$ Selanjutnya dalam pasal tersebut juga menentukan bahwa pilihan penyelesaian sengketa lingkungan hidup dilakukan secara suka rela oleh para pihak yang bersengketa. Gugatanmelalui pengadilan hanya dapat ditempuh apabila upaya penyelesaian sengketa di luar pengadilan yang dipilih dinyatakan tidak

\footnotetext{
${ }^{22}$ Undang-Undang Nomor 32 Tahun 2009 tentang Perlindungan dan Pengelolaan Lingkungan Hidup, Pasal 84

${ }^{23}$ Undang-Undang Nomor 32 Tahun 2009 tentang Perlindungan dan Pengelolaan LingkunganHidup, Pasal 65 Ayat 1

${ }^{24}$ Undang-Undang Nomor 32 Tahun 2009 tentang Perlindungan dan Pengelolaan LingkunganHidup, Pasal 67.

${ }^{25}$ Undang-Undang Nomor 32 Tahun 2009 tentang Perlindungan dan Pengelolaan LingkunganHidup,Pasal 84.
} 
berhasil oleh salah satu atau para pihak yang bersengketa.

Berikut akan dijelaskan masingmasingbentuk penyelesaian sengketa lingkungan hidup di luar pengadilan.

1). Arbitrase

Penyelesaian sengketa melalui arbritase berarti dengan cara menyerahkan kepada pihak ketiga (netral) yang mempunyai wewenang untuk memutuskan perkara. Menurut ketentuan Pasal 1 angka 1 Undang-undang Nomor 30 Tahun 1999, arbitrase adalah cara penyelesaian satuperkara perdata di luar peradilan umum yang didasarkan pada perjanjian arbitrase yang dibuatsecara tertulis oleh para pihak yang bersengketa.

2). Mediasi

Orang yang menjadi penengah disebut mediator. Dalam penyelesaian sengketa lingkungan hidup, apabila antara kedua pihak tidak dapat menyelesaikan sendiri sengketa yang mereka hadapi, mereka dapat menggunakan pihak ketiga yang netral untuk membantu mereka mencapai persetujuan atau kesepakatan. Mediasi sendiri diatur dalam Pasal 6 ayat (3), (4) dan (5) Undang-undang No. 30 Tahun 1999.

3). Negosiasi

Negosiasi adalah proses tawar menawar yang bersifat konsensus yang di dalamnya para pihakb erusaha memperoleh atau mencapai persetujuan tentang hal-hal yang disengketakan atau yang berpotensi menimbulkan sengketa. Para pihak yang bersengketa berhadapan langsung secara seksama dalam mendiskusikan permasalahan yang mereka hadapi secara korporatifdan saling terbuka.

\section{b. Penyelesaian Kasus Pencemaran dan/ atau Perusakan Lingkungan melalui Jalur Pengadilan}

Sebagaimana ditentukan dalam Undang-undang Nomor 32 tahun 2009 bahwa penyelesaian sengketa lingkungan hidup dapat ditempuh melalui pengadilan atau di luar pengadilan. ${ }^{26}$

1) Ganti Kerugian dan Pemulihan Lingkungan

Setiap penanggung jawab usaha dan/ atau kegiatan yang melakukan perbuatan melanggar hukum berupa pencemaran dan/ atau perusakan lingkungan hidup yang menimbulkan kerugian pada orang lain atau lingkungan hidup wajib membayar ganti rugi dan/atau melakukan tindakan tertentu.

bahwa selain diharuskan membayar ganti rugi, pencemar dan/atau perusak lingkungan hidup dapat pula dibebani oleh hakim untuk melakukan tindakan hukum tertentu, misalnya perintah untuk:

a) memasang atau memperbaiki unit pengolahan limbah sehingga limbah sesuai dengan bakumutu lingkungan hidup yang ditentukan;

b) memulihkan fungsi lingkungan hidup; dan/ atau

c) menghilangkan atau memusnahkan penyebab timbulnya pencemaran dan/ atau perusakan lingkungan hidup. ${ }^{27}$

\section{2).Tanggung Jawab Mutlak/ Strict Liability \\ Menurut ketentuan Undang-} undang Nomor 32 tahun 2009 bahwa setiap orangyang tindakannya, usahanya, dan/ atau kegiatannya menggunakan B3,

${ }^{26}$ Undang-Undang Nomor 32 Tahun 2009 tentang Perlindungan dan Pengelolaan Lingkungan Hidup, Pasal 84.

${ }^{27}$ Undang-Undang Nomor 32 Tahun 2009 tentang Perlindungan dan Pengelolaan Lingkungan Hidup, Pasal 87 Ayat (1) 
menghasilkan dan/atau mengelola limbah B3, dan/ atau yang menimbulkan ancaman serius terhadap lingkungan hidup bertanggung jawab mutlak atas kerugian yang terjadi tanpa perlu pembuktian unsur kesalahan. ${ }^{28}$

4) Tenggang Kedaluwarsa untuk Pengajuan Gugatan

Tenggat kedaluwarsa untuk mengajukan gugatan ke pengadilan mengikuti tenggang waktu sebagaimana diatur dalam ketentuan Kitab UndangUndang Hukum Perdata dan dihitung sejak diketahui adanya pencemaran dan/atau kerusakan lingkungan hidup. Ketentuan mengenai tenggat kedaluwarsa tidak berlaku terhadap pencemaran dan/atau kerusakan lingkungan hidup yang diakibatkan oleh usaha dan/atau kegiatan yang menggunakan dan/atau mengelola B3 serta menghasilkan dan/atau mengelola limbah B3. ${ }^{29}$

5) Hak Gugat Pemerintah dan Pemerintah Daerah

Instansi pemerintah dan pemerintah daerah yang bertanggung jawab di bidang lingkungan hidup berwenang mengajukan gugatan ganti rugi dan tindakan tertentu terhadap usaha dan/atau kegiatan yang menyebabkan pencemaran dan/atau kerusakan lingkungan hidup yang mengakibatkan kerugian lingkungan hidup.

6). Hak Gugat Masyarakat

${ }^{28}$ Undang-Undang Nomor 32 Tahun 2009 tentang Perlindungan dan Pengelolaan Lingkungan Hidup, Pasal 88.

${ }^{29}$ Undang-Undang Nomor 32 Tahun 2009 tentang Perlindungan dan Pengelolaan Lingkungan Hidup,Pasal 89.
Masyarakat berhak mengajukan gugatan perwakilan kelompok untuk kepentingan dirinya sendiri dan/ atau untuk kepentingan masyarakat apabila mengalami kerugian akibat pencemaran dan/atau kerusakan lingkungan hidup. Gugatan dapat diajukan apabila terdapat kesamaan fakta atau peristiwa, dasar hukum, serta jenis tuntutan di antara wakil kelompok dan anggota kelompoknya. ${ }^{30}$

\section{7). Hak Gugat Organisasi Lingkungan Hidup}

Dalam rangka pelaksanaan tanggung jawab perlindungan dan pengelolaan lingkungan hidup,organisasi lingkungan hidup berhak mengajukan gugatan untuk kepentingan pelestarian fungsi lingkungan hidup. Hak mengajukan gugatan terbatas pada tuntutan untuk melakukan tindakan tertentu tanpa adanya tuntutan ganti rugi, kecuali biaya atau pengeluaran riil.

8) Penyelesaian sengketa melalui jalur Pidana

Tindak pidana lingkungan hidup di Indonesia saat ini dapat dikategorikan sebagai administrative penal law atau public welfare offenses yang memberi kesan ringannya perbuatan tersebut. Dalam hal ini fungsi hukum pidana bersifat menunjang sanksi-sanksi administratif untuk ditaatinya norma-norma hukum administrasi.

\section{B. Penegakan Hukum Lingkungan di Indonesia.}

Dasar konstitusional pengelolaan Iingkungan atau sumber daya alam di

${ }^{30}$ Undang-Undang Nomor 32 Tahun 2009 tentang Perlindungan dan Pengelolaan Lingkungan Hidup,Pasal 91. 
negara kita ini tercantum dalam Pasal UUD 1945 yang menegaskan, bahwa "bumi air dan kekayaan alam yang terkandung d dalamnya dikuasai oleh negara dan dipergunakan untuk sebesarbesamya kemakmuran rakyat." 31

Hak negara untuk menguasai dan mengatur kekayaan negara yang terkandung di dalamnya ini, kemudian diterjemahkan oleh UU No. 32 Tahun 2009, di mana dalam perlindungan dan pengelolaan lingkungan hidup, pemerintah bertugas dan berwenang: ${ }^{32}$

\section{Bentuk-Bentuk Perlindungan Kepada Masyarakat Dalam Sengketa Lingkungan Hidup \\ 1. Perlindungan Hukum Dalam UU PPLH}

UU PPLH telah memberikan pengaturan bahwa setiap orang berhak atas lingkungan hidup yang baik dan sehat sebagai bagian dari hak asasi manusia. Setiap orang berhak mendapatkan pendidikan lingkungan hidup, akses informasi, akses partisipasi, dan akses keadilan dalam memenuhi hak atas lingkungan hidup yang baik dan sehat. Setiap orang berhak melakukan pengaduan akibat dugaan pencemaran dan/atau perusakan lingkungan hidup. Ketentuan lebih lanjut mengenai tata cara pengaduan sebagaimana dimaksud diatur dengan Peraturan Menteri. ${ }^{33}$

Dalam Pasal 68 UU PPLH diatur bahwa setiap orang yang

\footnotetext{
${ }^{31}$ Undang-Undang Dasar Negara Replublik IndonesiaTahun 1945 Pasal 33Ayat (3).

${ }^{32}$ Undang-Undang Nomor 32 Tahun 2009 tentang Perlindungan dan Pengelolaan Lingkungan Hidup, Pasal 63.

${ }^{33}$ Undang-Undang Nomor 32 Tahun 2009 tentang Perlindungan dan Pengelolaan Lingkungan Hidup, Pasal 65 Ayat (1) - (6).
}

melakukan usaha dan/atau kegiatan berkewajiban:

a. Memberikan informasi yang terkait dengan perlindungan dan pengelolaan lingkungan hidup secara benar, akurat, terbuka,dan tepat waktu;

b. Menjaga keberlanjutan fungsi lingkungan hidup; dan

c. Menaati ketentuan tentang baku mutu lingkungan hidup dan/atau kriteria baku kerusakan lingkungan hidup.

\section{Perlindugan dalam Penegakan Hukum Lingkungan.}

Penegakan hukum lingkungan dalam rangka pengendalian pencemaran udara dapat dibedakan dalam tiga aspek: (i) penegakan hukum lingkungan administratif oleh aparatur pemerintah, (ii) penegakan hukuml ingkungan kepidanaan yang dilakukan melalui prosedur yuridis peradilan, dan (iii) penegakan hukum lingkungan keperdataan serta "environmental disputes resolution" yang ditempuh secara litigasi maupun nonlitigasi.

\section{Kendala Dalam Penegakan Hukum di Indonesia.}

Bumi merupakan tempat tinggal
makhluk hidup dengan segala
keseimbangan yang ada didalamnya. Kerusakan lingkungan hidup dapat berakibat fatal bagi kelangsungan hidup manusia. Oleh karena itu sumberdaya alam dan lingkungan hidup pun harus dilindungi. Namun sayangnya kejahatan terhadap lingkungan hidup di Indonesia masih kerap terjadi. Hukum terkait Lingkungan Hidup menjadi instrumen yang penting dalam usaha menyelamatkan 
lingkungan hidup. Berikut ini merupakan Faktor Penghambat Penegakan Hukum Lingkungan di Indonesia.

\section{Kurangnya Sosialiasi Kepada Masyarakat Terkait Hukum Lingkungan}

Penegakan hukum lingkungan ini pun jauh lebih rumit dari pada delik lain, karena seperti telah dikemukakan sebelumnya hukum lingkungan menempati titik silang berbagai pendapat hukum klasik. Proses penegakan hukum administratif akan lain dari pada proses penegakan hukum perdata maupuan hukum pidana. Menurut Hamzah (2005:51) pada umumnya masalah dimulai pada satu titik, yaitu terjadinya pelanggaran hukum lingkungan. Dari titik perangkat ini dapat dimulai dari orang pribadi anggota masyarakat, korban penegak hukum yang mengetahui langsung terjadinya pelanggaran tanpa adanya laporan atau pengaduan. Tujuan tempat pelapor kepada Bapedal LSM atau organisasi lingkungan hidup jika ingin memilih jalan perdata terutama tuntutan perbuatan melanggar hukum dapat melakukan gugatan sendiri kepada hakim perdata atas nama masyarakat (algemen belang, maatschappelijk belang).

\section{Kendala Dalam Pembuktian}

Untuk dapat membuktikan bahwa suatu perbuatan telah menimbulkan pencemaran perlu penyidikan, penyidikan ini dilakukan oleh aparat POLRI. Untuk itu di samping diperlukan kemampuan dan keuletan setiap petugas, juga diperlukan suatu model yang dapat digunakan untuk menentukan apakah suatu perbuatan telah memenuhi unsur pasal Undang-Undang Nomor 4 Tahun 1982, ${ }^{34}$

\section{Infrastruktur Penegakan Hukum}

Kesulitan utama yang kerap dinyatakan oleh pemerintah atau aparat penegak hukum dalam mengatasi pembakaran hutan adalah minimnya aparat pemantau, atau minimnya alat bukti. Dalam hal tertangkap tangan maka yang dijerat adalah para operator yang notabene adalah pekerja harian. Perusahaan selalu dapat lepas dari jeratan hukum. Kompleksitas masalah pembakaran hutan bukan tanpa jalan keluar.

\section{Budaya Hukum yang Masih Buruk.}

Pada beberapa kasus, kejahatan lingkungan terjadi karena masih kentalnya budaya korupsi, kolusi dan nepotisme antara perusahaan-perusahaan, pemerintah maupun DPR. Lobi-lobi illegal masih sering terjadi.

Apabila hendak melihat keberhasilan perlindungan terhadap lingkungan hidup, sebaiknya kita tidak hanya sibuk memperbaiki sistem dan habitat politik dari hukum, tetapi juga menempatkan orang-orang dengan visi terhadap perlindungan lingkungan dalam jabatan-jabatan pada pilar-pilar penegakan hukum tersebut.

\section{E. Kedudukan Masyarakat Dalam Penanganan Sengketa Lingkungan Hidup}

\section{Fungsi Gugatan}

Secara luas masyarakat dalam UU PPLH mendapatkan pelindungan hukum yang kuat. Pasal 1 angka 31

${ }^{34}$ Undang-Undang Nomor 4 Tahun 1982, tentang Ketentuan-Ketentuan Pokok Pengelolaan Lingkungan Hidup Pasal 22. 
UU PPLH secara spesifik telah menentukan bahwa masyarakat hukum adat adalah kelompok masyarakat yang secara turun temurun bermukim di wilayah geografis tertentu karena adanya ikatan pada asal usul leluhur, adanya hubungan yang kuat dengan lingkungan hidup, serta adanya sistem nilai yang menentukan pranata ekonomi, politik, sosial, dan hukum. Gugatan lingkungan dalam rangka penyelesaian sengketa lingkungan melalui lembaga peradilan merupakan langkah penting untuk mengawali prosedur hukum litigasi.

\section{Peraturan Yang Mendukung.}

Dalam Penjelasan Umum UUPPLH juga diungkapkan bahwa upaya preventif dalam rangka pengendalian dampak lingkungan hidup perlu dilaksanakan dengan mendaya gunakan secara maksimal instrumen pengawasan dan perizinan.

Undang-Undang ini juga mendaya gunakan berbagai ketentuan hukum, baik hukum administrasi, hukum perdata, maupun hukum pidana. Ketentuan hukum perdata meliputi penyelesaian sengketa lingkungan hidup di luar pengadilan dan di dalam pengadilan. Penyelesaian sengketa lingkungan hidup di dalam pengadilan meliputi gugatan perwakilan kelompok, hak gugat organisasi lingkungan, ataupun hak gugat pemerintah. Melalui cara tersebut diharapkan selain akan menimbulkan efek jera juga akan meningkatkan kesadaran seluruh pemangku kepentingan tentang betapa pentingnya perlindungan dan pengelolaan lingkungan hidup demi kehidupan generasi masa kini dan masa depan.

Peran penting masyarakat diatur jelas dalam Pasal 70 UU PPLH bahwa masyarakat memiliki hak dan kesempatan yang sama dan selualuasnya untuk berperan aktif dalam perlindungan dan pengelolaan lingkungan hidup. Peran masyarakat dapat berupa:

a. Pengawasan sosial;

b. Pemberian saran, pendapat, usul, keberatan, pengaduan; dan/atau

c. Penyampaian informasi dan/atau laporan. Peran masyarakat dilakukan untuk:

1) meningkatkan kepedulian dalam perlindungan dan pengelolaan lingkungan hidup;

2) meningkatkan kemandirian, keberdayaan masyarakat, dan kemitraan;

3) Menumbuh kembangkan kemampuan dan kepeloporan masyarakat;

4) Menumbuh kembangkan ketanggap segeraan masyarakat untuk melakukan pengawasan sosial; dan

5) mengembangkan dan menjaga budaya dan kearifan lokal dalam rangka pelestarian fungsi lingkungan hidup.

\section{PENUTUP}

\section{A. Kesimpulan}

1. Ketentuan hukum penyelesaian sengketa lingkungan dalam Undang-undang tentang Perlindungan dan Pengelolaan Lingkungan Hidup (UUPPLH) tertuang pada Pasal 84-93. Berdasarkan Pasal 84 UU PPLH, terdapat dua jalur sarana 
hukum ("legal means") penyelesaian sengketa lingkungan : melalui forum pengadilan (Pasal 87-93) dan di luar pengadilan (Pasal 85-86). Penyelesaian sengketa lingkungan melalui sarana pengadilan("litigationprocess" "adversary system") dilakukan dengan mengajukan gugatan lingkungan sebagaimana dirumuskan oleh Pasal 87 UU PPLH.

2. Terhadap kasus pencemaran dan/atau perusakan lingkungan hidup yang diselesaikan melalui jalur pengadilan, pada umumnya belum memberikan perlindungan hukum pada korban. Dengan menjatuhkan sanksi pidana kepada pelaku seolah-olah sudah dirasa cukup. Tidak ada sanksi kewajiban membayar ganti kerugian oleh pelaku kepada korban, walaupun dalam UU No 23 tahun 2003 dan UUPPLH 2009 mengatur sanksi pidana tambahan terhadap korporasi berupa melakukan tindakan tertentu. Jika mau menggugat ganti kerugian bisa dilakukan melalui jalur keperdataan tetapi memerlukan waktu lama dan ganti kerugian yang didapat tidak seimbang dengan biaya yang dikeluarkan.

\section{B. Saran}

1. Perlu dilakukan refomasi undangundang lingkungan hidup yang memberikan perlindungan hukum terhadap korban dan mengadakan kelengkapan regulasi untuk pelaksanaan Undang-Undang Perlindungan dan Pengelolaan Lingkungan Hidup.

2.Pertanggungjawaban pelaku pencemaran dan/atau perusakan lingkungan tidak cukup hanya dikenakan sanksi pidana namun juga bertanggung jawab kepada korban dan perlu dibuat aturan
pelaksanaannya.Sehingga implementasi perlindungan hukum terhadap korban pencemaran dan/ atau perusakan lingkungan hidup dapat terwujut. Selanjutnya untuk melengkapi hasil penelitian ini dapat dilanjutkan penelitian yang lebih lengkap. Sesuai perkembangan hukum yang ada

\section{Daftar Bacaan}

\section{Buku}

Abdurrahman, Pengantar Hukum Lingkungan Indonesia, P.T. Citra Bakti, Bandung, 1990.

DanuSaputro, Munadjat, Hukum Lingkungan ( Dalam Pencemaran Lingkungan) Melandasi Sistem Hukum Pencemaran, Buku V, ,Bina cipta, Bandung, 1986.

DanuSaputro, Munadjat, Hukum Lingkungan Buku I ,Bina cipta, Bandung, 1980

Harjdasoemantri, Koesnadi, Hukum Tata Lingkungan, Press, Yogyakarta, 1996.

Marzuki, Peter Mahmud, Penelitian Hukum, Penerbit Kencana, Jakarta, 2006.

Marzuki, Peter Mahmud, Pengantar Ilmu Hukum, Kencana Prada Media Grop, Jakarta, 2008.

Mertokusumo, Sudikno, MengenalHukum (Suatu

Pengantar),Liberty, Yogyakarta, 1999

Muhamad, Abdulkadir, Hukum dan penelitian hukum, Citra Aditya bakti, Bandung, 2004.

Rahmadi, Takdir, Hukum Lingkungan di Indonesia, rajawali Pers, Jakarta, 2014.

Rungkuti, Siti Sundari, Hukum Lingkungan dan Kebijaksanaan Lingkungan Dalam Proses 
pembangunan Hukum Nasional Indonesia, Press, Surabaya, 1987.

Soekanto, Soerjono, Penelitian Hukum, UI Press, Jakarta 1986.

Soerjani, Mohamat, Ahmad, Rofiq, Munir, Rozi, Lingkungan: Sumber Daya Alam Dan Kependudukan Dalam Pembangunan, UI Press, Jakarta, 1987.

Sunggono, Bambang, Metodologi Penelitian Hukum, Raja Grafindo, Jakarta, 2007.

Sutamihardja, R.T.M, Kualitas dan Pencemaran Lingkungan, Institut Teknologi Bogor, Bogor. 1978.

Wijoyo, Suparto, Karakteristik Hukum Acara Peradilan Administrasi,Airlangga University Press, Edisi Kedua, Surabaya, 2005.

Undang-undang Dasar Negara Repuplik Indonesia Tahun 1945

Undang-Undang Nomor 3 tahun 2014 tentangPerindustrian

Undang-Undang Nomor 4 Tahun 1982 tentang Ketentuan - Ketentuan Pokok Pengelolaan Lingkungan Hidup

Undang-Undang Nomor 23 Tahun 1997 tentang Pengelolaan Lingkungan Hidup

Undang-undang Nomor 30 Tahun 1999 Tentang Abritase Alternatif Penyelesaian Sengketa.

Undang-undang Nomor 32 Tahun 2009 Tentang Perlindungan dan Pengelolalan Lingkungan Hidup.

Undang-undang Nomor 40 Tahun 2007 Tentang Perseroan Terbatas.

Undang-undang Nomor 27 Tahun 1999 Tentang Analisis Mengenai Dampak Lingkungan.

Peraturan pemerintah Nomor 27 Tahun 2012 tentang Perizinan Lingkungan

Perarturan Pemerintah Nomor54 Tahun 2000 Tentang Lembaga Penyedia jasa Pelayanan Penyelesaian Sengketa lingkungan Hidup.
Keppres Nomor 55 tahun 1991,Tentang Susunan Organisasi dan Tata Kerja Kejaksaan Republik Indonesia.

Peraturan Menteri Lingkungan Hidup Nomor 4 Tahun 2013 tentang Pedoman Penyelesaian Sengketa Lingkungan Hidup

Suparto Wijoyo. Pengkajian Hukum Tentang Perlindungan Kepada Masyarakat

Dalam Sengketa Lingkungan Hidup, Kementerian Hukum Dan Hak Asasi Manusia Republik Indonesia Badan Pembinaan Hukum Nasional, Jakarta , 2013

Yeni Widowaty, Fadia Fitriyanti, Membangun Model Perlindungan Hukum terhadap Masyarakat Sebagai Korban Pencemaran Dan/Atau Perusakan Lingkungan Oleh Korporasi Dengan Prinsip Restorative Justice, Fakultas Hukum Universitas Muhammadiyah Yogyakarta.

Sovia Hasanah, S.H. Hukuman Bagi Perusahaan Pelaku Pencemaran Lingkungan

https://www.hukumonline.com/klinik/detai 1/ulasan/lt57ff10d6bb0af/hukumanbagi-perusahaan-pelakupencemaran-lingkungan/ di unduh tanggal 15 September 2019

Dr. Suprapto Wijoyo, Pengkajian hukum tentang perlindungan masyarakat dalam sengketa lingkunganhidup https://www.bphn.go.id/data/docume nts/laphir_lingkungan_hidup.pdf diunduh tanggal 15 september 2019

AntonioRichardoSimanugkalit, https://ww w.kompasiana.com/antoniorichardos imanungkalit/54f8b109a33311ea168 b4746/keselarasan-hukumperindustrian-dengan-hukumlingkungan-dalam-menjaminterciptanya-lingkungan-yang-baik diunduh tanggal 31 Maret 2020 